\title{
Klimaatrisico's, aansprakelijkheden en enkele toezichtrechtelijke aspecten
}

\author{
Mr. W. Kloostermanen mr. M. Kuilman*
}

\section{Inleiding}

De focus op duurzaamheid is de afgelopen jaren fors toegenomen. In internationaal en Europees verband worden meer afspraken gemaakt en instrumenten ontwikkeld om de ongewenste gevolgen van klimaatverandering te adresseren. De duurzame ontwikkelingsdoelstellingen (Sustainable Development Goals (SDGs)) ${ }^{1}$ en het Klimaatakkoord van Parijs, ${ }^{2}$ beide opgesteld door de Verenigde Naties (VN), worden mondiaal onderschreven. Ook ondernemingen zijn op zoek naar duurzame oplossingen, beleggen duurzaam en leggen verantwoording af op het gebied van duurzaamheid, onder meer door middel van het publiceren van hun $\mathrm{CO}_{2}$-footprint of door het onderschrijven van zelfregulering, zoals de OECD Guidelines for Multinational Enterprises (de OESO-richtlijnen), ${ }^{3}$ de Equator Principles III, ${ }^{4}$ de Principles on Climate Obligation of Enterprises, ${ }^{5}$ het Klimaatstatement Banken van de Nederlandse Vereniging van Banken, ${ }^{6}$ het Convenant internationaal maatschappelijk verantwoord beleggen in de verzekeringssector ${ }^{7}$ en de Code Pensioenfondsen. ${ }^{8}$ Deze inspanningen zijn in eerste instantie gericht op het terugdringen van de ongewenste gevolgen van klimaatverandering in de (nabije) toekomst. Sommige ondernemingen worden al geconfronteerd met de effecten van klimaatverandering. Claims en aansprakelijkstellingen, fysieke risico's en de economische gevolgen van energietransitie zijn actueel.

In deze bijdrage gaan wij in op de gevolgen van klimaatverandering voor financiële ondernemingen (de klimaatrisico's) en op enkele toezichtrechtelijke aspecten. Bij de bespreking van de klimaatrisico's maken we onderscheid tussen (1) claimrisico's en aansprakelijkheden, (2) transitierisico's en (3) fysieke

\footnotetext{
Mr. W. Kloosterman en mr. M. Kuilman zijn werkzaam bij De Nederlandsche Bank.

Deze bijdrage is geschreven op persoonlijke titel. De bijdrage is op 18 oktober 2018 afgesloten.

1. Zie www.un.org/sustainabledevelopment/sustainable-developmentgoals/.

2. Zie unfccc.int/paris_agreement/items/9485.php.

3. Zie mneguidelines.oecd.org/guidelines/.

4. Zie equator-principles.com/members-reporting/.

5. Zie climateprinciplesforenterprises.org/.

6. Zie www.nvb.nl/publicaties/position-papers-statements/1386/klimaat statement-nederlandse-banken.html.

7. Zie www.imvoconvenanten.nl/verzekeringssector/news/2018/7/verzeke ringssector-maakt-afspraken.

8. Zie https://www.pensioenfederatie.nl/website/publicaties/servicedocu
} menten/code-pensioenfondsen-2018. risico's. We zullen zien dat deze risico's een impact kunnen hebben op bedrijfsmodellen van financiële ondernemingen en (uiteindelijk) een gevaar kunnen vormen voor de continuïteit van financiële ondernemingen. Vervolgens kijken we of de prudentiële toezichthouders, de Europese Centrale Bank (ECB) en De Nederlandsche Bank (DNB), de wijze waarop financiële ondernemingen klimaatrisico's in bedrijfsmodellen signaleren en mitigeren in het toezicht kunnen betrekken. In deze bijdrage staat de positie van banken en verzekeraars centraal; andere typen financiële ondernemingen, zoals beleggingsondernemingen, beleggingsinstellingen en pensioenfondsen, laten wij buiten beschouwing.

\section{Verschillende verschijningsvormen klimaatrisico's}

In dit artikel maken wij onderscheid tussen drie categorieën klimaatgerelateerde financiële risico's: (1) claimrisico's en aansprakelijkheden, (2) transitierisico's en (3) fysieke risico's. ${ }^{9}$ Claimrisico's manifesteren zich in het geval dat een onderneming aansprakelijk wordt gehouden op grond van onrechtmatige daad voor schade die het gevolg is van klimaatverandering (art. 6:162 van het Burgerlijk Wetboek (BW)), of wanneer een onderneming wordt aangesproken op de nakoming van haar verplichtingen. Transitierisico's zijn risico's verbonden aan de energietransitie en de overgang naar een klimaatneutrale economie als gevolg van nieuwe of veranderende wet- en regelgeving, klimaatbeleid, technologische ontwikkelingen of veranderende voorkeuren van consumenten. Onder fysieke risico's verstaan we directe schade als gevolg van klimaatverandering, bijvoorbeeld door een hagelstorm. Claimrisico's, transitierisico's en fysieke risico's kunnen onder meer leiden tot operationele risico's en kredietrisico's voor ondernemingen. Deze klimaatrisico's kunnen de onderneming direct treffen, maar ook indirect, bijvoorbeeld omdat de onderneming kredietrisico loopt op een andere onderneming die te maken

9. Zie ook het rapport van DNB: M. Regelink e.a., De Nederlandse financiele sector veilig achter de dijken. Een nadere verkenning naar klimaatgerelateerde financiële risico's, 2017. In dit rapport wordt al onderscheid gemaakt tussen fysieke risico's en transitierisico's. Zie ook E. Campiglio, Y. Dafermos, P. Monnin, J. Ryan-Collins, G. Schotten \& M. Tanaka, Climate Change Challenges for Central Banks and Financial Regulators, Nature 2018, afl. 6, p. 462-468. 
heeft met een massaclaim, ${ }^{10}$ door nieuwe wet- en regelgeving (en hogere kosten of boetes bij niet-naleving) ${ }^{11}$ of doordat zij met de directe fysieke gevolgen van klimaatverandering wordt geconfronteerd. In beginsel kunnen deze risico's zich voordoen bij alle typen ondernemingen, waaronder financiële ondernemingen.

\subsection{Claimrisico's en aansprakelijkheden}

Claimrisico's en aansprakelijkheden manifesteren zich in het geval een financiële onderneming aansprakelijk wordt gehouden op grond van onrechtmatige daad (art. 6:162 BW) voor schade die het gevolg is van klimaatverandering, en - indirect - indien een financiële onderneming aan deze risico's wordt blootgesteld, bijvoorbeeld omdat de onderneming kredietrisico loopt op een (andere) onderneming die met een dergelijke claim wordt geconfronteerd. Ook uit anderen hoofde dan onrechtmatige daad kunnen financiële ondernemingen worden aangesproken, bijvoorbeeld ter zake de naleving van contractuele verplichtingen of vanwege dwaling rondom gedane uitingen in het kader van de dienstverlening. Hierna bespreken wij de recente casuïstiek rondom de aansprakelijkheidstelling voor schade die het gevolg is van klimaatverandering vanwege het niet naleven van de zorgplicht en enkele overige claimrisico's en aansprakelijkheden.

\section{Zorgplicht}

De meest opmerkelijke uitspraak met betrekking tot de gevaarlijke gevolgen van klimaatverandering betreft de klimaatzaak van Stichting Urgenda tegen de Staat der Nederlanden. Naar eigen zeggen is Urgenda de eerste ter wereld die een overheid ter verantwoording heeft geroepen om maatregelen te nemen tegen klimaatverandering. ${ }^{12}$ De Rechtbank Den Haag deed op 24 juni 2015 uitspraak in eerste aanleg. ${ }^{13}$ De rechtbank oordeelde dat de Nederlandse overheid tegenover Urgenda onzorgvuldig en daarmee onrechtmatig heeft gehandeld door voor het jaar 2020 uit te gaan van een lagere reductiedoelstelling dan $25 \%$ broeikasgassen ten opzichte van het jaar $1990 .^{14}$

10. Hierbij kan worden gedacht aan de zaak van Milieudefensie tegen Shell, waaraan verderop in dit artikel nog kort aandacht wordt besteed. Indien Milieudefensie gelijk krijgt, kan dit voor Shell grote financiële gevolgen hebben, die weer gevolgen kunnen hebben voor de financiële ondernemingen die bijvoorbeeld geïnvesteerd hebben in Shell of financieringen hebben verstrekt aan Shell.

11. Denk hier bijvoorbeeld aan de boerenbedrijven die in de problemen zijn gekomen door de nieuwe wet- en regelgeving omtrent fosfaatrechten. Deze boerenbedrijven hebben vaak in de afgelopen jaren flink geïnvesteerd in uitbreiding van hun veestapels, waarvoor banken mogelijk financieringen verstrekt hebben. $\mathrm{Na}$ invoering van de nieuwe wetgeving zouden de boeren hun veestapels moeten reduceren, waardoor een groot aantal boeren in grote financiële problemen dreigt te komen. Hierdoor lopen banken dan weer kredietrisico. Zie bijv. Honderden boerenbedrijven in de problemen door nieuwe mestregels. Kabinet weigert hulp, Omroep Brabant 17 mei 2018, en Rechter haalt opnieuw streep door mestregels voor melkveehouders, NOS 9 augustus 2017, NOS.nl.

12. Zie www.urgenda.nl/themas/klimaat-en-energie/klimaatzaak/.

13. Rb. Den Haag 24 juni 2015, ECLI:NL:RBDHA:2015:7145.

14. R.o. 4.93 .
Recentelijk heeft het Gerechtshof Den Haag de uitspraak van de rechtbank bekrachtigd. ${ }^{15}$ Waar de rechtbank echter van mening was dat Urgenda geen rechtstreeks beroep kon doen op art. 2 en 8 van het Europees Verdrag tot bescherming van de rechten van de mens en de fundamentele vrijheden (EVRM), oordeelt het hof juist op grond van deze bepalingen dat de Staat zijn zorgplicht schendt. ${ }^{16}$ In art. 2 en 8 EVRM worden het recht op leven en het recht op respect voor het privéleven, het familieleven, de woning en correspondentie vastgelegd. Volgens het hof rust op de Staat de positieve verplichting om concrete handelingen te verrichten ter voorkoming van een toekomstige aantasting van de belangen die zijn neergelegd in art. 2 en 8 EVRM. Het hof merkt op dat wanneer de overheid weet dat er sprake is van een reëel en onmiddellijk dreigend gevaar, de Staat preventieve maatregelen moet nemen om de aantasting zo veel mogelijk te voorkomen. In het licht van deze invulling van art. 2 en 8 EVRM is het hof van oordeel dat de Staat zijn zorgplicht heeft geschonden. ${ }^{17}$ Het hof heeft aangegeven dat een reductieverplichting van $25 \%$ per eind 2020, zoals bevolen door de rechtbank, naar het oordeel van het hof in lijn is met de zorgplicht van de Staat. ${ }^{18}$ Het hof concludeert dan ook dat de Staat onrechtmatig handelt door verdere reductie per eind 2020 na te laten. $\mathrm{Nu}$ het hof oordeelt dat er sprake is van een schending van de mensenrechten, lijkt deze uitspraak gestoeld op een stevigere juridische basis dan de uitspraak van de rechtbank. De Staat kan tegen deze uitspraak nog cassatieberoep instellen.

De uitspraken zijn opmerkelijk. In deze uitspraken is voor het eerst een zorgplicht voor de Staat aangenomen om maatregelen te treffen ter voorkoming van gevaarlijke klimaatverandering.

Ook ondernemingen worden ter verantwoording geroepen voor hun aandeel in de schade als gevolg van klimaatverandering. Bij brief van 4 april 2018 aan de CEO van Royal Dutch Shell plc stelt Milieudefensie Shell aansprakelijk uit hoofde van onrechtmatige daad. ${ }^{19}$ Milieudefensie is van mening dat Shell haar wettelijke zorgplicht schendt doordat zij met haar bedrijfsactiviteiten en strategie wereldwijd klimaatschade veroorzaakt en de doelstellingen die zijn overeengekomen in het Klimaatakkoord van Parijs hierdoor worden ondermijnd. Volgens Milieudefensie zijn de activiteiten van Shell 'een gevaar voor de mensheid, de mensenrechten, de toekomstige generaties en het milieu'. Milieudefensie eist dat Shell haar beleid en investeringen in lijn brengt met het Klimaatakkoord van Parijs, in die zin dat zij haar uitstoot in 2050 dient terug te brengen naar nul. Een ander voorbeeld betreft de procedure

15. Hof Den Haag 9 oktober 2018, ECLI:NL:GHDHA:2018:2591.

16. De rechtbank was van oordeel dat op grond van art. 34 EVRM door Urgenda geen rechtstreeks beroep op art. 2 en 8 EVRM mogelijk was. Het hof is echter van mening dat art. 34 EVRM alleen betrekking heeft op de toegang tot het EHRM en dat het EVRM hiermee geen uitsluitsel geeft over de toegang tot de Nederlandse rechter, zie r.o. 35 .

17. R.o. $40-43$.

18. R.o. 53.

19. Deze brief is te vinden via de site www.milieudefensie.nl. 
aangespannen door een Peruaanse boer tegen het Duitse energiebedrijf RWE inzake de vergoeding van kosten voor het aanleggen van dammen en het treffen van andere maatregelen om de overstroming van een gletsjermeer het hoofd te bieden. De Peruaanse boer betoogt dat het gletsjermeer en het nabijgelegen dorpje waar de boer woont, dreigen te overstromen door het smelten van (een) gletsjer(s) als gevolg van de activiteiten van RWE. Hoewel de rechtbank in 2016 de vordering op grond van de onrechtmatige daad nog niet-ontvankelijk verklaarde vanwege het ontbreken van het causaal verband, ${ }^{20}$ is de claim in hoger beroep wél ontvankelijk verklaard. De Peruaanse boer is nu aan zet om aan te tonen waar het causale verband uit bestaat. Het Oberlandesgericht Hamm heeft hierbij een aantal vragen gesteld die de Peruaanse boer moet beantwoorden. Zo moet hij aantonen dat de woningen waar het in deze zaak om draait daadwerkelijk gevaar lopen bij het overlopen van het gletsjermeer en/of het zich voordoen van een lawine. Daarnaast wordt de Peruaanse boer gevraagd om te bewijzen dat de $\mathrm{CO}_{2}$ die RWE uitstoot daadwerkelijk opstijgt naar de atmosfeer en daar leidt tot een hogere dichtheid van broeikasgassen, en dat de toename van deze broeikasgassen daadwerkelijk een verhoging van de temperatuur tot gevolg heeft. Voor sommige van deze vragen zal het bewijs door de Peruaanse boer relatief makkelijk te leveren zijn. Waar het echter gaat om bijvoorbeeld het aantonen dat de $\mathrm{CO}_{2}$-uitstoot door RWE specifiek leidt tot een hogere dichtheid van broeikasgassen, lijkt ons dit lastiger. De vraag is hierbij of de Duitse rechter verwacht dat de Peruaanse boer het causale verband tussen de uitstoot van broeikasgassen en de temperatuurstijging in zijn algemeenheid bewijst, of het causaal verband tussen de specifieke uitstoot door RWE en de temperatuurstijging die het smelten van de gletsjer tot gevolg heeft. Indien dit laatste het geval is, is het ons inziens zeer moeilijk voor de boer om dit te bewijzen. In de media wordt deze uitspraak aangehaald als voorbeeld voor het adagium 'de vervuiler betaalt'.

Bovenstaande laat zien dat aansprakelijkstelling voor schending van klimaatnormen mogelijk is én - in het geval van Urgenda/de Staat - ook al is aangenomen. Aansprakelijkstelling van financiële ondernemingen voor schade als gevolg van klimaatverandering lijkt echter niet snel in de rede te liggen, het causale verband zal immers moeilijk aan te tonen zijn. Op dit moment is er - voor zover wij hebben kunnen nagaan ook nog geen rechtszaak aangespannen tegen een financiële onderneming van deze aard. Toch valt ons inziens niet uit te sluiten dat financiële ondernemingen verantwoordelijk kunnen worden gehouden voor hun bijdrage aan klimaatverandering. Financiële ondernemingen zijn verantwoordelijk voor hun eigen handelen en kunnen zelf maatregelen nemen (klimaatneutraal gebouw, stimuleren van kortere woon-werkafstand, uitsluiten van betrokkenheid bij milieuvervuilende projecten/financieringen, het niet langer verstrekken van leningen aan vervuilende bedrijven, enzovoort). Indien ze dit niet (tijdig) doen, kunnen ze worden geconfronteerd met een

20. Landgericht Essen 15 december 2016, zaak 14/0354Z/R/rv (Lliuya/ RWE AG). aansprakelijkstelling vanwege een mogelijke schending van hun zorgplicht. Een parallel kan worden getrokken met een asbest-casus uit het verleden. In zijn arrest van 2 oktober $1998^{21}$ oordeelde de Hoge Raad dat, ook al was werken met asbest gebruikelijk en maatschappelijk aanvaard, waren in andere vergelijkbare bedrijven ook minder of geen veiligheidsmaatregelen getroffen en was gebruik van asbest voorgeschreven, de werkgever (de onderneming) toch tekort was geschoten. De reden hiervoor was dat de werkgever veiligheidsmaatregelen had moeten nemen, omdat de gevaren die verbonden waren aan het werken met asbest reeds bekend waren of behoorden te zijn. Voorstelbaar is dat toekomstige jurisprudentie omtrent klimaatverandering op eenzelfde manier zou kunnen worden ingestoken. Immers, de gevaren van klimaatverandering zijn reeds bekend in het maatschappelijk verkeer en de acties die ondernomen moeten worden om het tij te keren inmiddels ook. Het feit dat er (nu nog) geen wettelijke voorschriften bestaan die (financiële) ondernemingen verplichten in hun beleid en activiteiten rekening te houden met hun bijdrage aan de klimaatverandering, ${ }^{22}$ en dat concurrerende bedrijven evenmin maatregelen treffen, betekent niet dat een onderneming niet aansprakelijk kan worden gehouden voor schade als het gevolg van klimaatverandering.

Dat de aansprakelijkstelling van financiële ondernemingen voor de gevolgen van klimaatverandering wel degelijk in de rede ligt, wordt ook geillustreerd door de melding van Friends of the Earth Europe en Friends of the Earth Netherlands in samenwerking met Milieudefensie tegen Rabobank bij het Nationaal Contactpunt OESO-richtlijnen (hierna: NCP). De klacht dateert (al) van 27 juni 2014 en luidt als volgt: ${ }^{23}$

'Rabobank had not taken the appropriate steps to prevent or mitigate alleged negative impacts related to their activity through their business relationship with Bumitama Agri Group (BGA), which was partially funded by Rabobank.'

De klacht ziet op de betrokkenheid van Rabobank bij de palmolie-industrie, waarvan bekend is dat deze zeer schadelijk is voor het milieu. Hierna is een jarenlang bemiddelingstraject gestart, waarover het NCP in de evaluatie van het traject schrijft dat alle partijen zich inzetten voor verbetering. Ook uit de website van de Rabobank blijkt dat de bank zich inzet voor $100 \%$ duurzame palmolie in $2020 .^{24}$

21. HR 2 oktober 1998, NJ 1999/683 m.nt. Vranken, VR 1999/114 (Cijsouw/De Schelde II).

22. Zie par. 2.2 voor een opsomming van richtlijnen en wetten die momenteel al wel voor financiële ondernemingen gelden.

23. De melding is te vinden via de volgende pagina van het ministerie van Buitenlandse Zaken: https://www.oesorichtlijnen.nl/meldingen/ documenten/publicatie/2014/12/16/ncp-eerste-evaluatie-friends-of-theearth-milieudefensie---rabobank.

24. Zie www.milieudefensie.nl en https://www.rabobank.com/nl/aboutrabobank/background-stories/food-agribusiness/sustainable-palm-oilbattle-has-to-be-won.html. 


\section{Overige claimrisico's en aansprakelijkheden}

Naast bovengenoemde zorgplicht zijn er ook andere claimrisico's en aansprakelijkheden waar financiële ondernemingen rekening mee moeten houden. Zo geldt voor een bank of verzekeraar die bepaalde richtsnoeren (zelfregulering) heeft onderschreven, bijvoorbeeld via de Nederlandse Vereniging van Banken of het Verbond van Verzekeraars, dat er een (bindende) verplichting ontstaat jegens de andere ondernemingen die de richtsnoeren hebben onderschreven om aan de betreffende richtsnoeren te voldoen. Voldoet de bank of verzekeraar niet, dan kan de onderneming op het niet naleven van zelfregulering worden aangesproken door andere partijen en stakeholders. Een voorbeeld hiervan is ook de eerdergenoemde procedure tegen Rabobank bij het NCP. De Rabobank heeft immers de OESO-richtlijnen onderschreven en werd mede aangesproken op het handelen in strijd met deze richtlijnen. ${ }^{25}$ Daarnaast kan zelfregulering onderdeel worden van de overeenkomst tussen een bank of verzekeraar en een klant. Dit kan bijvoorbeeld indien de bank of verzekeraar in zijn voorwaarden aangeeft bepaalde richtsnoeren, zoals de SDGs van de $\mathrm{VN}$, te onderschrijven en/of daarnaar te handelen. Wanneer een bank of verzekeraar niet voldoet aan deze zelfopgelegde richtsnoeren, kan de klant de bank of verzekeraar hierop aanspreken en eventuele schade vorderen uit hoofde van wanprestatie. ${ }^{26}$ Ook is het denkbaar dat de klant de overeenkomst met een bank of een verzekeraar ontbindt of vernietigt op grond van dwaling (art. 6:228 BW), namelijk indien blijkt dat de klant een overeenkomst is angegaan in de veronderstelling dat de bank of verzekeraar bepaalde zelfregulering zou naleven. Daarnaast zou een actie op grond van onrechtmatige daad mogelijk kunnen zijn als kan worden vastgesteld dat er sprake is van een misleidende handelspraktijk van een bank of verzekeraar (art. 6:193a e.v. BW). Krachtens art. 6:193g onder a $\mathrm{BW}$ is het beweren aan een gedragscode gebonden te zijn en daarnaar te handelen, wanneer dit niet het geval is, misleidend. Indien een bank of verzekeraar een gedragscode heeft onderschreven, bijvoorbeeld de Code Duurzaam Beleggen of het Convenant internationaal maatschappelijk verantwoord beleggen in de verzekeringssector, en hiermee adverteert (op

25. Zie in dit verband ook de melding door Oxfam Novib, Greenpeace, BankTrack en Milieudefensie op 8 mei 2017 bij het NCP van een mogelijke overtreding van de OESO-richtlijnen door ING. In de melding geven Oxfam Novib, Greenpeace, BankTrack en Milieudefensie aan dat zij menen dat ING de OESO-richtlijnen op het gebied van milieu en klimaat schendt en verzoeken zij het NCP om het klimaatbeleid van ING tegen het licht te houden en ING zo nodig aan te sporen om het (klimaat)beleid in overeenstemming te brengen met de OESO-richtlijnen. Aan de klacht werd in de media de nodige aandacht besteed. Zie bijv. ING onder vuur om financiering fossiele-energiebedrijven, NOS 8 mei 2017.

26. Immers, de klant heeft de overeenkomst mogelijk mede gesloten juist omdat de bank of verzekeraar bepaalde richtsnoeren heeft onderschreven. Door vervolgens in strijd te handelen met de betreffende richtsnoeren pleegt de bank of verzekeraar wanprestatie. Schade die hiervan het gevolg is, zal moeilijk vast te stellen zijn. Schade waar men bijvoorbeeld aan zou kunnen denken, is wanneer een klant van een bank bij een concurrent een hogere rente had kunnen krijgen, maar heeft gekozen voor een groen product met een lagere rente. De klant zou in dat geval de misgelopen rente kunnen vorderen. de website, reclameposters, enzovoort), en blijkt dat een bank of verzekeraar zich hier niet aan houdt, kan de bank of verzekeraar hierop worden aangesproken.

Tot slot kan een financiële onderneming worden aangesproken op het niet of te laat voldoen aan de wet- en regelgeving of maatregelen ter zake de energietransitie en de overgang naar een klimaatneutrale economie. Afhankelijk van de relatie tussen de onderneming en de klant kan de klant een actie instellen uit hoofde van wanprestatie of onrechtmatige daad en schadevergoeding vorderen. Deze schade kan bijvoorbeeld bestaan uit het doorbelasten van (hogere) kosten voor het (alsnog) voldoen aan wet- en regelgeving, waar deze kosten lager zouden zijn geweest wanneer op tijd was voldaan aan de weten regelgeving. Uit onderzoek blijkt dat de kosten van de energietransitie namelijk beheersbaar zijn wanneer hiertoe geleidelijk wordt overgegaan. Wanneer echter een acute transitie moet plaatsvinden, kan dit ook voor financiële ondernemingen grote gevolgen hebben. Zo kunnen zij te maken krijgen met een plotselinge afwaardering van $\mathrm{CO}_{2}$-intensieve activa. ${ }^{27}$ Zie verder paragraaf 2.2.

Het is ons inziens niet lastig voor te stellen dat voornoemde acties een dermate grote impact kunnen hebben, met name in het geval van massaclaims of indien het vertrouwen in de onderneming verloren geraakt, dat dit ernstige gevolgen voor de bedrijfsvoering meebrengt.

\subsection{Transitierisico's}

Transitierisico's zijn risico's verbonden aan de overgang van fossiele brandstoffen naar duurzame energie, zoals zonne- en windenergie (de energietransitie) en de overgang naar een klimaatneutrale economie meer in het algemeen. Deze risico's zijn het gevolg van nieuwe of veranderende wet- en regelgeving, klimaatbeleid, technologische ontwikkelingen of veranderende voorkeuren van consumenten en kunnen financiële ondernemingen direct, maar ook indirect treffen.

\section{Energietransitie}

Een van de aspecten van de energietransitie betreft het terugdringen van de uitstoot van $\mathrm{CO}_{2}$. Sinds 2005 reguleert het Europese Emissiehandelssysteem (ETS) de uitstoot van $\mathrm{CO}_{2}$. Krachtens het ETS worden aan energie-intensieve ondernemingen $\mathrm{CO}_{2}$-emissierechten toegewezen en kunnen deze rechten worden verhandeld. De hoeveelheid toegewezen emissierechten wordt bepaald op grond van productieniveaus in het verleden en de $\mathrm{CO}_{2}$-intensiteit van productieprocessen. De prijs van de emissierechten is op dit moment echter dermate laag, dat de invoering van het ETS de uitstoot van $\mathrm{CO}_{2}$ niet heeft verlaagd. Er heerst dan ook al langere tijd een (Europese) discussie over de vraag of er al dan niet een minimumprijs moet worden ingesteld voor emissierechten. De Europese Commissie heeft in 2017 besloten om de hoeveelheid emissierechten te verkleinen, waardoor de uitstoot duurder wordt en

27. Zie het rapport van DNB: G. Schotten e.a., Tijd voor transitie. Een verkenning van de overgang naar een klimaatneutrale economie, 2016, p. 67. 
de ondernemingen hopelijk groener worden. ${ }^{28}$ Aanscherping of beperking van de regelgeving kan ertoe leiden dat ondernemingen meer kosten moeten maken en het operationeel risico toeneemt. Financiële ondernemingen worden indirect geraakt; zij krijgen te maken met een hoger kredietrisico en operationeel risico op energie-intensieve bedrijven. Daarnaast zal, als gevolg van de transitie naar een lagere $\mathrm{CO}_{2}$-uitstoot (bijvoorbeeld door een hogere prijs van $\mathrm{CO}_{2}$-emissierechten of een belasting op de uitstoot van $\mathrm{CO}_{2}$ ), een deel van de huidige olie-, kolen- en gasreserves niet meer worden gebruikt (dit wordt ook wel de koolstofzeepbel-hypothese ('carbon bubble') genoemd). Het kan zijn dat de huidige, daadwerkelijke boekwaarde van deze fossiele brandstoffen lager is dan waarvoor zij momenteel in de boeken staan. Banken zullen rekening moeten houden met een mogelijke afwaardering en verminderde kredietwaardigheid van de ondernemingen die hun waarde en/of inkomsten voor een groot deel baseren op fossiele brandstoffen. Afhankelijk van het moment en de schaal waarop de vraag naar fossiele brandstoffen daalt, kan er zelfs sprake zijn van een risico voor de stabiliteit van het financiële stelsel als geheel. ${ }^{29}$

Andere voorbeelden van wet- en regelgeving en maatregelen met betrekking tot de energietransitie zien op gebouwen. ${ }^{30} \mathrm{De}$ Europese richtlijn betreffende de energieprestatie van gebouwen schrijft voor dat alle nieuwbouw vanaf 2020 bijna energieneutraal moet zijn en energie in belangrijke mate dient voort te komen uit hernieuwbare bronnen. ${ }^{31}$ Daarnaast heeft de voormalig minister voor Wonen en Rijksdienst aangekondigd dat vanaf 2023 een verplicht energielabel C voor kantoorpanden zal worden geintroduceerd. ${ }^{32}$ Banken en verzekeraars zullen uiteraard zelf aan deze nieuwe wet- en regelgeving moeten voldoen en hun huisvesting eventueel moeten aanpassen. Voor banken geldt daarnaast dat zij met deze toekomstige regelgeving rekening moeten houden bij de financiering van panden die nog niet energieneutraal zijn en geen energielabel C hebben. Het financieren van deze panden kan risico's met zich brengen, nu de verhuurbaarheid en verkoopbaarheid na 2023 een probleem kunnen worden, omdat dan niet langer aan de geldende wetgeving wordt voldaan. ${ }^{33}$ Het onderpand voor de financiering wordt hierdoor minder waard en de kredietwaardigheid van ondernemingen die deze panden exploiteren, neemt af.

28. EU sluit akkoord over emissierechten, NRC Handelsblad 10 november 2017, nrc.nl.

29. Campiglio e.a. 2018. Klimaatrisico's kunnen mogelijk leiden tot een systeemrisico.

30. Richtlijn 2010/31/EU van het Europees Parlement en de Raad van 19 mei 2010 betreffende de energieprestatie van gebouwen (PbEU 2010, L $153 / 13$ ).

31. In Nederland is deze richtlijn geïmplementeerd door wijziging van de Woningwet en enige andere wetten en in werking getreden per 1 januari 2013. Zie ook Kamerstukken II 2011/12, 33124, 2.

32. Zie www.rijksoverheid.nl/documenten/kamerstukken/2016/11/28/ kamerbrief-over-energiebesparing-gebouwde-omgeving.

33. Zie www.rvo.nl/onderwerpen/duurzaam-ondernemen/gebouwen/wetten -en-regels-gebouwen/bestaande-bouw/energielabel-c-kantoren/ veelgestelde-vragen-energielabel-c-kantoren.

\section{Overgang naar klimaatneutrale economie}

Naast de regelgeving inzake de energietransitie worden meer in het algemeen regels gesteld met betrekking tot de overgang naar een klimaatneutrale economie. Een aantal van deze regels is direct van toepassing op financiële ondernemingen. Om te voldoen aan deze (nieuwe) regels zullen financiële ondernemingen kosten moeten maken en kan het operationeel risico toenemen.

Een voorbeeld van nieuwe regelgeving is de Richtlijn met betrekking tot de bekendmaking van niet-financiële informatie (NFI), die geldt voor jaarverslagen over boekjaren die aanvangen op of na 1 januari $2017 .{ }^{34}$ Deze richtlijn is in Nederland geimplementeerd via het Besluit bekendmaking van nietfinanciële informatie en het Besluit bekendmaking diversiteit. Krachtens deze richtlijn en de besluiten geldt de verplichting voor ondernemingen met meer dan 500 werknemers om wezenlijke informatie over belangrijke ecologische, sociale en governanceaspecten (niet-financiële informatie) openbaar te maken.

Een ander voorbeeld betreft nieuwe wetgeving ter uitvoering van het actieplan van de Europese Commissie voor duurzame financieringen, dat onlangs is gepubliceerd. ${ }^{35}$ In het plan kondigt de Europese Commissie aan dat in de loop van 2018 wetgevingsvoorstellen zullen worden ingediend teneinde (onder meer) (1) te garanderen dat geleidelijk een EU-taxonomie (EU-classificatiesysteem) wordt ontwikkeld voor duurzame activiteiten (actiepunt 1), (2) de herziene Richtlijn markten voor financiële instrumenten (MiFID II) te wijzigen om te garanderen dat tijdens de geschiktheidsbeoordeling rekening wordt gehouden met duurzaamheidsvoorkeuren (actiepunt 4), en (3) de verplichtingen van institutionele beleggers en vermogensbeheerders ten aanzien van duurzaamheidsoverwegingen te verduidelijken (actiepunt 7). De verschillende in het actieplan genoemde wetgevingsvoorstellen en initiatieven kunnen van grote invloed zijn op de bedrijfsvoering van financiële ondernemingen. Zo geeft het actieplan aan dat het bij het opstellen van een EU-taxonomie noodzakelijk is dat voor financiële producten productnormen worden ontwikkeld met betrekking tot klimaat-, milieu- en sociale factoren en dat prudentiële regels moeten worden opgesteld. ${ }^{36}$ Ook gaat de Commissie onderzoeken of het haalbaar is dat risico's in verband met klimaatverandering en andere milieufactoren in het risicobeheerbeleid van instellingen moeten worden opgenomen en of de kapitaalsvereisten hier mogelijk op aangepast

34. Richtlijn 2014/95/EU van het Europees Parlement en de Raad van 22 oktober 2014 tot wijziging van Richtlijn 2013/34/EU met betrekking tot de bekendmaking van niet-financiële informatie en informatie inzake diversiteit door bepaalde grote ondernemingen en groepen (PbEU 2014, L 330/1).

35. Het actieplan is te vinden op: eur-lex.europa.eu/legal-content/NL/ALL/? uri=CELEX:52018DC0097. Het actieplan volgt voor een groot gedeelte de bevindingen uit het rapport van de High-Level Expert Group on Sustainable Finance (HLEG) van januari 2018.

36. Zie bijlage I bij het actieplan van de Europese Commissie voor duurzame financieringen. 
dienen te worden. Daarnaast worden in 2019 de richtsnoeren inzake niet-financiële informatie herzien. In de herziene richtsnoeren zullen ondernemingen worden geadviseerd over de wijze waarop klimaatgerelateerde informatie openbaar moet worden gemaakt. Dit zijn slechts enkele voorbeelden van wetgevingsvoorstellen en initiatieven die voortvloeien uit het actieplan, die directe invloed zullen hebben op de bedrijfsvoering van financiële ondernemingen. Financiële ondernemingen zullen rekening moeten houden met deze initiatieven en nieuwe regelgeving.

Ook de nieuwe Klimaatwet moet hier worden genoemd. In het verlengde van de uitspraak van de rechtbank inzake Urgenda/de Staat (zie par. 2.1) zijn de onderhandelaars van de Tweede Kamer het zeer recent eens geworden over een tekstvoorstel voor de nieuwe Klimaatwet. Het voorstel poogt de wijze waarop het Nederlandse klimaatbeleid invulling geeft aan het Klimaatakkoord van Parijs te verankeren en heeft als doelstelling om de uitstoot van broeikasgassen te verlagen. ${ }^{37}$ Hoewel het voorstel in eerste instantie is gericht tot de overheid, kunnen wij het ons goed voorstellen dat hieruit voorschriften en maatregelen volgen voor de financiële sector en financiële ondernemingen. Uit de toelichting bij het voorstel volgt immers dat de regering bij het opstellen van het periodieke klimaatplan aan zal geven welke maatregelen voor de komende periode mogelijk zijn per sector, zodat actoren zich daarop kunnen instellen. ${ }^{38}$

\subsection{Fysieke risico's}

Tot slot bespreken we kort de fysieke risico's. Deze risico's ontstaan als gevolg van onverwachte extreme weersomstandigheden. Te denken valt aan schade door een hagelstorm, sneeuwstorm, overstroming, hittegolf en extreme droogte. Het is de verwachting dat extreme weersomstandigheden in toenemende mate zullen plaatsvinden. ${ }^{39}$ Fysieke risico's doen zich in de eerste plaats voor bij verzekeraars. (On)verwachte uitkering van grote sommen kan directe gevolgen hebben voor het bedrijfsmodel en het risicomanagement van verzekeraars. ${ }^{40}$ Ter illustratie: een hagelstorm in 2016 zorgde voor een schadeclaim van $€ 500$ miljoen voor de verzekeraars, aldus het Verbond van Verzekeraars. ${ }^{41}$ Dit leidde ertoe dat het resultaat van een aantal verzekeraars over het boekjaar 2016 lager was dan voorzien. ${ }^{42}$ Ook banken kunnen met (de indirecte gevolgen

37. Kamerstukken II 2016/17, 34534, 6 .

38. Kamerstukken II 2016/17, 34534, 7, p. 13.

39. Zie het rapport van de KNMI van 2014, KNMI'14 klimaatscenario's voor Nederland, herziene uitgave 2015.

40. Zie ook het rapport van DNB: Regelink e.a. 2017, p. 8.

41. Minstens $€ 500 \mathrm{mln}$ schade door noodweer, Het Financieele Dagblad 28 juli 2016.

42. Het betreft hier o.a. Achmea en ASR. In het persbericht van 14 maart 2017, waarin Achmea haar jaarresultaten over 2016 presenteerde, merkt de bestuursvoorzitter van Achmea op dat het resultaat onder meer werd beïnvloed door de hagelcalamiteit die in juni 2016 voor meer dan $€ 300$ miljoen aan schade veroorzaakte bij meer dan 30.000 klanten. Zie nieuws. achmea.nl/?q=jaarresultaten+2016\&search. $x=0$ \&search.y=0. Voor ASR, zie berichtgeving in: Hagelschade drukt resultaat ASR, NRC Handelsblad 18 november 2016 . van) fysieke risico's van klimaatverandering worden geconfronteerd. Zo kan het bijvoorbeeld zijn dat een kastuinder als gevolg van de hagelstorm schade lijdt, voor welke schade de kastuinder niet is verzekerd. De schade kan dermate groot zijn, dat de kastuinder niet meer kan voldoen aan zijn betalingsverplichting aan de bank. Dientengevolge loopt de bank (groter) kredietrisico op de tuinder.

\section{Enkele toezichtrechtelijke aspecten van klimaatrisico's}

Hiervoor hebben we gezien wat de civielrechtelijke gevolgen zijn van klimaatverandering voor financiële ondernemingen, en meer in het bijzonder banken en verzekeraars. De klimaatrisico's kunnen een materiële impact hebben op bedrijfsmodellen van financiële ondernemingen en kunnen (uiteindelijk) een gevaar vormen voor de continuiteit. In deze paragraaf komen enkele toezichtrechtelijke aspecten van klimaatrisico's aan bod, kijken we naar het mandaat van $\mathrm{DNB}$ en van de $\mathrm{ECB}$, en of $\mathrm{DNB}$ en de $\mathrm{ECB}$ (in het geval van banken) toezicht kunnen uitoefenen op de wijze waarop deze risico's in bedrijfsmodellen worden gesignaleerd en gemitigeerd.

\subsection{Het toezicht op klimaatrisico's door DNB}

DNB heeft tot taak het uitoefenen van prudentieel toezicht op financiële ondernemingen en het beslissen omtrent de toelating van financiële ondernemingen tot de financiële markten, alsmede de afwikkeling van bepaalde financiële ondernemingen. ${ }^{43}$ Het prudentieel toezicht is gericht op de soliditeit van financiële ondernemingen en de stabiliteit van het financiële stelsel. ${ }^{44} \mathrm{Als}$ onderdeel daarvan toetst DNB of een financiële onderneming aan de eisen van een integere en beheerste bedrijfsuitoefening voldoet (art. 3:10 jo. art. 3:17 van de Wet op het financieel toezicht (Wft)).

Uit art. 3:17 lid 2 onder a, b en c Wft volgt dat bij of krachtens algemene maatregel van bestuur regels kunnen worden gesteld met betrekking tot (a) het beheersen van bedrijfsprocessen en bedrijfsrisico's, (b) de integriteit en (c) de soliditeit van de financiële onderneming, waaronder wordt verstaan het beheersen van financiële risico's en andere risico's die de soliditeit van de financiële onderneming kunnen aantasten. Art. 3:17 lid 2 onder c Wft betreft onder andere een implementatie van art. 74 en 76 e.v. CRD IV. ${ }^{45}$ De vraag is of klimaatrisico's ook als risico's in de zin van art. 3:17 lid 2 onder c Wft en art. 74 CRD IV kwalificeren.

De risico's die worden genoemd in art. 3:17 lid 2 onder c Wft worden nader uitgewerkt in art. 23 van het Besluit prudentiële

43. Art. 1:24 lid $2 \mathrm{Wft}$.

44. Art. 1:24 lid $2 \mathrm{Wft}$.

45. Richtlijn 2013/36/EU van het Europees Parlement en de Raad van 26 juni 2013 betreffende toegang tot het bedrijf van kredietinstellingen en het prudentieel toezicht op kredietinstellingen en beleggingsondernemingen, tot wijziging van Richtlijn 2002/87/EG en tot intrekking van de Richtlijnen 2006/48/EG en 2006/49/EG (PbEU 2013, L 176/338) (CRD IV). 
regels Wft (Bpr). ${ }^{46}$ Art. 23 Bpr bepaalt dat onder risico's in het bijzonder moeten worden verstaan het concentratierisico, krediet- en tegenpartijrisico, liquiditeitsrisico, marktrisico, operationeel risico, renterisico voortvloeiend uit niet-handelsactiviteiten, restrisico, risico van buitensporige hefboomwerking, securitisatierisico, verzekeringsrisico en afkooprisico. ${ }^{47}$ Voor zover de gevolgen van klimaatverandering voor een onderneming leiden tot een van deze risico's, bijvoorbeeld kredietrisico, tegenpartijrisico of operationeel risico, kunnen klimaatrisico's als relevant risico in de zin van art. 3:17 lid 2 onder $\mathrm{c} \mathrm{Wft}$ worden aangemerkt. ${ }^{48}$ Maar ook voor klimaatrisico's die niet direct het gevolg hebben dat een van de risico's in art. 23 Bpr zich voordoet, zou kunnen worden betoogd dat er sprake is van een relevant prudentieel risico waarop art. 3:17 lid 2 onder $\mathrm{c}$ Wft van toepassing is. Uit de parlementaire geschiedenis bij art. 3:17 Wft volgt dat het niet alleen financiële risico's betreft, maar ook juridische en operationele risico's die een gevaar kunnen zijn voor de soliditeit van de onderneming. Art. 3:17 lid 2 aanhef en onder c Wft kadert de risico's in kwestie slechts in tot financiële risico's en andere risico's die de soliditeit van de onderneming kunnen aantasten. De opsomming van risico's in art. $23 \mathrm{Bpr}$ is echter geen limitatieve opsomming. Art. 3:17 lid 2 aanhef en onder c Wft laat ruimte voor andere risico's die de soliditeit van de onderneming kunnen aantasten. Dit hoeven niet enkel directe, financiële risico's te zijn, maar kunnen ook andere, 'nieuwe' risico's zijn, zoals klimaatrisico's, die een impact kunnen hebben op de soliditeit van de onderneming. ${ }^{49}$ In de vorige paragraaf hebben we betoogd dat klimaatrisico's een aanzienlijke impact kunnen hebben op financiële ondernemingen. Ons inziens kunnen klimaatrisico's derhalve worden gekwalificeerd als relevante prudentiële risico's waarop art. 3:17 lid 2 onder c Wft van toepassing is, en kan DNB deze risico's en de wijze waarop banken en verzekeraars deze risico's signaleren en mitigeren, in haar toezicht betrekken.

Bij de praktische invulling van dit toezicht kan worden gedacht aan toezicht op de analyse ten aanzien van de klimaatrisico's. DNB kijkt dan naar de methodologie en de data die ten grondslag liggen aan de analyse van de klimaatrisico's door ondernemingen. ${ }^{50}$ In lijn met de behandeling van de andere voor de bedrijfsvoering relevante risico's kan van ondernemingen worden verwacht dat zij mitigerende maatregelen treffen ten aanzien van de klimaatrisico's. Wanneer een financiële onderneming de risico's en bijbehorende mitigerende maatregelen in kaart heeft gebracht, blijven de nettorisico's over. De nettorisico's zouden vervolgens DNB aanleiding kunnen

46. Art. 23 Bpr betreft een implementatie van art. 76 e.v. CRD IV.

47. Het verzekeringsrisico en het afkooprisico worden niet genoemd in CRD IV en zijn met name relevant bij verzekeraars.

48. Hetzelfde zou moeten gelden voor de uitleg van art. 74 CRD IV.

49. Zie ook European Banking Authority, Risk Assessment of the European Banking System, november 2017, waarin de EBA risico's gerelateerd aan cybersecurity en dataveiligheid als nieuwe risico's benoemt. Deze risico's zullen doorgaans als operationeel risico kwalificeren.

50. DNB verricht zelf ook onderzoek. Zie de rapporten van DNB: Schotten e.a. 2016 en Regelink e.a. 2017. geven tot bijvoorbeeld het opleggen van kapitaalseisen, het aanhouden van extra kapitaal om onverwachte verliezen op kredietuitzetting op te vangen (in het geval van banken) of verplichtingen na te komen (in het geval van verzekeraars) en andere prudentiële maatregelen. Of de mogelijkheid bestaat om op basis van de nettoklimaatrisico's extra kapitaaleisen op te leggen, is nog een punt van discussie. De Europese Commissie heeft in haar actieplan in ieder geval wel aangegeven te gaan onderzoeken of de kapitaalvereisten dienen te worden bijgesteld. Hoewel in het actieplan vooral wordt aangestuurd op het aanpassen van kapitaalsvereisten als ondersteuning voor de duurzame financiering, en dus op het aanpassen van kapitaalsvereisten in positieve zin, is het ons inziens niet ondenkbaar dat daarbij ook wordt gekeken naar de mogelijkheid van het opleggen van aanvullende kapitaalsvereisten in verband met de klimaatrisico's waarmee financiële ondernemingen zich geconfronteerd zien. ${ }^{51}$

Voor banken is het van belang dat deze conclusie (en de eventuele praktische invulling daarvan) ook opgaat voor het toezicht dat wordt uitgeoefend door de ECB. Immers, sinds de inwerkingtreding van het Single Supervisory Mechanism (SSM) in november 2014 is de ECB de prudentiële toezichthouder ten aanzien van banken. ${ }^{52}$

\subsection{Het toezicht op klimaatrisico's door de ECB}

De ECB heeft centralebanktaken en specifieke toezichttaken. Tot de centralebanktaken behoren het handhaven van de prijsstabiliteit en het ondersteunen van het algemene economische beleid in de Europese Unie. ${ }^{53}$ De specifieke toezichttaken zien op het microprudentieel toezicht op kredietinstellingen die zijn gevestigd in deelnemende lidstaten en staan in de SSM-verordening. ${ }^{54}$ Deze taken zijn, onder meer: (1) het verlenen en intrekken van bankvergunningen, (2) het beoordelen van aanvragen voor verklaringen van geen bezwaar (vvgb's) voor het verwerven of afstoten van gekwalificeerde deelnemin-

51. Zie p. 10 van het actieplan.

52. Art. 127 lid 6 VWEU. Het doorlopend toezicht op minder significante banken ligt nog bij de nationale toezichthouders, waaronder DNB.

53. Art. 127 lid 1 VWEU jo. art. 3 lid 3 VEU. Art. 127 lid 1 VWEU luidt als volgt: 'Het hoofddoel van het Europees Stelsel van Centrale Banken (hierna "ESCB" te noemen), is het handhaven van prijsstabiliteit. Onverminderd het doel van prijsstabiliteit ondersteunt het ESCB het algemene economische beleid in de Unie teneinde bij te dragen tot de verwezenlijking van de in artikel 3 van het Verdrag betreffende de Europese Unie omschreven doelstellingen van de Unie. Het ESCB handelt in overeenstemming met het beginsel van een open-markteconomie met vrije mededinging, waarbij een doelmatige allocatie van middelen wordt bevorderd, en met inachtneming van de beginselen die zijn neergelegd in artikel 119.' Art. 3 lid 3 VEU luidt als volgt: 'De Unie brengt een interne markt tot stand. Zij zet zich in voor de duurzame ontwikkeling van Europa, op basis van een evenwichtige economische groei en van prijsstabiliteit, een sociale markteconomie met een groot concurrentievermogen die gericht is op volledige werkgelegenheid en sociale vooruitgang, en van een hoog niveau van bescherming en verbetering van de kwaliteit van het milieu (...).'

54. Verordening (EU) 1024/2013 van de Raad van 15 oktober 2013 waarbij aan de Europese Centrale Bank specifieke taken worden opgedragen betreffende het beleid inzake het prudentieel toezicht op kredietinstellingen (PbEU 2013, L 287/63). 
gen in een bank, (3) het toezicht op de naleving van de eisen met betrekking tot onder meer vermogen en liquiditeit, en (4) het toezicht op de naleving van eisen met betrekking tot de beheerste bedrijfsvoering, waaronder de risicobeheersingsprocessen. ${ }^{55}$ Uit de SSM-verordening volgt daarnaast dat de ECB om de aan haar toebedeelde taken te verrichten, de nationale autoriteiten kan instrueren om hun eigen bevoegdheden uit te oefenen volgens de in de nationale wetgeving bepaalde voorwaarden, wanneer die bevoegdheden niet al in de SSM-verordening aan de ECB zijn toebedeeld. ${ }^{56}$ In dit verband is van belang dat de ECB bij brief van 31 maart 2017 heeft bekendgemaakt dat zij zich in het toezicht op significante banken ook (direct) competent beschouwt voor de uitoefening van specifieke microprudentiële bevoegdheden in de nationale wetgeving van deelnemende lidstaten, ook al zijn deze bevoegdheden niet expliciet te herleiden tot een duidelijke grondslag in het Unierecht. Daaronder valt ook (voor wat betreft de Nederlandse wetgeving) het beoordelen van een vvgb-aanvraag van een significante bank voor een deelneming in een andere bank of in een onderneming, een fusie, splitsing of vennootschappelijke reorganisatie, zoals bedoeld in art. 3:96 lid 1 Wft. ${ }^{57}$

In de SSM-verordening wordt de ECB aangemerkt als bevoegde autoriteit om de opgedragen taken uit te voeren. ${ }^{58}$ Daarbij wordt tevens bepaald dat de ECB met dat exclusieve oogmerk beschikt over alle in de SSM-verordening bepaalde bevoegdheden, en daarnaast over alle bevoegdheden die de bevoegde autoriteiten krachtens het toepasselijke Unierecht hebben. ${ }^{59}$ Onder Unierecht wordt verstaan verordeningen, nadere EUregelgeving, zoals Regulatory Technical Standards (in de vorm van gedelegeerde verordeningen) van de Europese Commissie en Guidelines van de European Banking Authority. In het geval van Unierecht in de vorm van richtlijnen past de ECB de nationale wetgeving toe waarin deze richtlijnen zijn omgezet, zoals de Wft. ${ }^{60}$ Hieruit volgt ons inziens dat, indien en voor zover DNB klimaatrisico's in haar toezichtraamwerk kan betrekken op basis van het toepasselijke materiële (Unie)recht en de bevoegdheid heeft om toezicht te houden op de naleving

55. Zie art. 4 SSM-verordening. Zie voor een nadere uitwerking van de bevoegdheden van de ECB o.a. B. Bierman \& L.J. Silverentand, De juridische en praktische gevolgen van het SSM: van het Frederiksplein naar de Kaiserstrasse, FR 2014, afl. 11, p. 441-452, K. Holtering, G.J.S. ter Kuile \& L. Wissink, De taken van DNB in het SSM-tijdperk, FR 2014, afl. 11, p. 453-461 en W.H. Bovenschen e.a., Europees bankentoezicht (SSM). Juridische en praktische perspectieven, NtER 2013, afl. 10, p. 365-373.

56. Art. 9 SSM-verordening, derde alinea.

57. De brief van de ECB is te vinden op: www.bankingsupervision.europa.eu/ banking/letterstobanks/html/index.en.html. De brief is op 20 juni 2017 op de website van de ECB gepubliceerd.

58. Art. 9 SSM-verordening, eerste alinea. De bevoegdheden van de ECB worden uitgewerkt in afd. 2 SSM-verordening.

59. Art. 9 SSM-verordening, tweede alinea. Dit gaat om alle bevoegdheden die aan bevoegde autoriteiten zijn toegekend in verordeningen en in nationale wetgeving ter implementatie van EU-richtlijnen, zoals bijv. Verordening (EU) 575/2013 van het Europees Parlement en de Raad van 26 juni 2013 betreffende prudentiële vereisten voor kredietinstellingen en beleggingsondernemingen en tot wijziging van Verordening (EU) 648/2012 (PbEU 2013, L 176/1) (CRR) en CRD IV.

60. Art. 4 lid 3 SSM-verordening jo. overweging 35. daarvan, de ECB dit in haar toezicht op Nederlandse banken ook zou kunnen doen. Dit betekent dat de ECB bijvoorbeeld bij het verlenen van bankvergunningen of een vvgb voor het verwerven of afstoten van gekwalificeerde deelnemingen in een bank, maar ook in het lopend toezicht, zou kunnen kijken naar de wijze waarop de betreffende bank klimaatrisico's mitigeert. $^{61}$

De vraag is of de ECB ook daadwerkelijk klimaatrisico's zal meenemen in haar toezichtraamwerk. In dit verband wijzen we op een recente brief van de ECB aan het Europees Parlement, waarin de ECB de uitdagingen omtrent klimaatverandering heeft onderkend en heeft opgemerkt dat het behalen van klimaatdoelen, onder meer neergelegd in het Klimaatakkoord van Parijs, van groot belang is voor de maatschappij. ${ }^{62}$ Uit deze brief volgt ook dat volgens de ECB het correct beprijzen en het in de gaten houden van financiële risico's verbonden aan klimaatverandering en milieufactoren van groot belang zijn bij het aanmoedigen van duurzame ontwikkeling en het behouden van een goed functionerend financieel systeem. ${ }^{63}$ De ECB ondersteunt de diverse commissies en expertgroepen die zich met dit onderwerp bezighouden en voorstellen doen ter bevordering van een duurzaam financieel systeem en het wegnemen van (juridische) bezwaren, waaronder de door de Europese Commissie ingestelde High-Level Expert Group on Sustainable Finance (HLEG). ${ }^{64}$ Wel merkt de ECB op dat wijzigingen in de regulatory frameworks, bijvoorbeeld ter integratie van klimaatrisico's in het regelgevend kader, altijd vanuit het prudentieel perspectief gelegitimeerd moeten zijn en niet het primaire doel van de prudentiële regelgeving mogen ondermijnen. Op basis van deze uitingen kan ons inziens niet worden uitgesloten dat de ECB in de (nabije) toekomst klimaatrisico's in haar toezicht op banken zal gaan betrekken.

\section{Afsluiting}

In deze bijdrage staan de gevolgen van klimaatverandering en de risico's voor financiële ondernemingen centraal. We hebben drie categorieën klimaatrisico's geïdentificeerd, te weten claimrisico's en aansprakelijkheden, transitierisico's en fysieke risico's, en getracht inzicht te geven in de wijze waarop deze risico's zich kunnen manifesteren bij banken en verzekeraars. We betogen dat klimaatrisico's en meer in het bijzonder de claimrisico's en aansprakelijkheden een materiële impact kunnen hebben voor bedrijfsmodellen van financiële ondernemingen. Financiële ondernemingen zullen zich van deze klimaatgerelateerde risico's moeten vergewissen. Daarnaast hebben we in deze bijdrage kort stilgestaan bij enkele toezichtrechtelijke aspecten van klimaatrisico's. We concluderen dat de gevolgen van klimaatverandering als relevant risico in de zin

61. Een van de vereisten voor een vergunning als kredietinstelling ziet op een integere en beheerste bedrijfsvoering. Zie art. 2:12 lid 1 onder $\mathrm{fWft}$.

62. De brief is te vinden via: www.ecb.europa.eu/home/search/html/index.en. html?q=L\%2FMD\%2F17\%2F383.

63. Zie noot 62 .

64. Zie https://ec.europa.eu/info/business-economy-euro/banking-andfinance/sustainable-finance_nl\#hleg. 


\section{Maandblad} Vermogensrecht

van art. 3:17 Wft kunnen worden gekwalificeerd en dat DNB en de ECB (in het geval van banken) toezicht kunnen uitoefenen op de wijze waarop klimaatrisico's worden geïdentificeerd en gemitigeerd. 